This is an author produced version of a paper published in CROP PROTECTION. This paper has been peer-reviewed and is proofcorrected, but does not include the journal pagination.

Citation for the published paper:

Wiik, L., Rosenqvist, H. (2010) The economics of fungicide use in winter wheat in southern Sweden. Crop Protection. Volume: 29

Number: 1, pp 11-19.

http://dx.doi.org/10.1016/j.cropro.2009.09.008

Access to the published version may require journal subscription.

Published with permission from: Elsevier

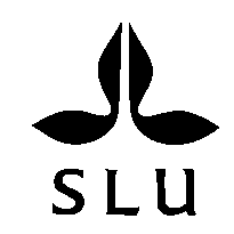

Epsilon Open Archive http://epsilon.slu.se 


\title{
The economics of fungicide use in winter wheat in southern Sweden
}

\author{
Lars Wiik $^{\text {a, * }}$, Håkan Rosenqvist ${ }^{\text {b }}$ \\ ${ }^{a}$ Swedish University of Agricultural Sciences, Department of Plant Protection Biology, PO \\ Box 102, SE-230 53 Alnarp, * Lars.Wiik@ltj.slu.se \\ ${ }^{\mathrm{b}}$ Swedish University of Agricultural Sciences, Department of Agriculture - Farming \\ Systems, Technology and Product Quality, PO Box 102, SE-230 53 Alnarp
}

\section{Abstract}

In southern Sweden, fungicide treatment of winter wheat is prevalent and recommended almost routinely against leaf blotch diseases. However, yield increases and hence the resulting net returns from fungicide use are highly variable within and between years. These variations raise questions about whether, when and how fungicides should be used. To help answer these questions, a thorough economic evaluation of fungicide use was carried out, based on results from untreated plots and fungicide-treated plots in trials in farmers' fields, 1983-2007. Scenarios with varying grain prices and costs of fungicide treatment were evaluated and examined. Doubling and tripling the grain price led to the largest impact on the net return from fungicide treatment, followed by increasing cost of the fungicide. Other costs were of minor importance. The mean net return from fungicide use was no more than $12 €$ ha $^{-1}$ over the 25 years (2008 grain prices and costs used in calculations). Furthermore, the mean net return was negative in 10 years and less than $50 \%$ of the entries were profitable to treat in 11 years. Changes over time and changes in controllable factors (e.g. fungicide and cultivar choice, crop rotation, techniques) and uncontrollable factors (e.g. emerging and new diseases, price relations) influenced the profitability of fungicide use. Fungicide use was in fact more profitable (mean net return 21 compared with $3 €$ ha $^{-1}$ ) during the latter part of the period (1995-2007) than in the earlier part (1983-1994). Improved decision support systems in a holistic framework based on sound economics are urgently needed. 
1 Keywords: plant disease, net-return, profitability, integrated pest management, Septoria

2 tritici.

\section{Introduction}

5 Many important diseases of winter wheat such as Leaf Blotch Diseases (LBDs, including 6 Septoria tritici blotch - the major leaf blotch disease in Sweden, Stagonospora nodorum 7 blotch and tan spot), powdery mildew, brown rust and yellow rust are effectively controlled

8 by fungicides and fungicide use has therefore been a standard procedure in many countries for decades (Cook and Jenkins, 1988; Wiik, 2009). In southern Sweden (Scania), fungicides are used by most farmers in winter wheat, especially against LBDs. According to actual official recommendations: 'With present grain prices fungicide input is most often profitable in the southern and central Sweden, but the optimal dose strongly fluctuates due to differences in disease intensity between years.’ (SCB/SJV, 2008; SJV, 2008).

In their review on the economic basis for protection against plant diseases, Ordish and Dufour (1969) declared the economics of diseases to be a somewhat neglected theme. Some years later Carlson and Main (1976) found economic models of biological systems to be too simple compared with the complex nature of such systems. Since then, the economic importance of plant diseases and the net return from control measures have been estimated now and then,

20 (Cook and King, 1984; Zadoks, 1984; Cook and Jenkins, 1988; Priestley and Bayles, 1988; Cooper and Dobson, 2007; Fabre et al., 2007). However, in our opinion the subject has still not been studied sufficiently to provide a good base for limitation and optimisation of control measures. Sundell (1980) made a rough estimate of crop losses in agricultural crops in

24 Sweden during the late 1970s and evaluated the possibilities of reducing these losses and the 25 economic consequences of different restrictions. He found host plant resistance to be the most 
1 profitable measure in the controlling of a number of fungal diseases, but he also found a

2 considerable short-term potential for increased use of fungicides and a marked increase in net

3 production costs when the use of pesticides was stopped. In a later evaluation by the Royal

4 Swedish Academy of Agriculture and Forestry, the economic losses caused by total omission

5 of fungicides and a $50 \%$ decrease of herbicides in cereals was estimated at $77 € \mathrm{ha}^{-1}$ (KSLA,

6 1989). More specifically, in winter wheat Wiik (1991) found fungicide treatment to be

7 decreasingly profitable at increasing cost levels (calculated in dt grain ha ${ }^{-1}$ ); $81 \%$ at cost level

$8 \quad 1 \mathrm{dt} \mathrm{ha}^{-1}$ and 33\% at cost level $6 \mathrm{dt} \mathrm{ha}^{-1}$ for 167 field trials in southern Sweden, and 68\% and

$9 \quad 13 \%$ respectively for 96 field trials in central Sweden.

The profitability of fungicide use in field trials carried out during 1983-2007 in southern Sweden was evaluated in a more thorough economic analysis than usual, supplemented with scenarios with different grain prices and fungicide treatment costs expected to be relevant in future assessments. The aim of the evaluation was to highlight economic considerations in wheat production and to examine the profitability of a single fungicide treatment at GS 45-61 in winter wheat.

\section{Materials and methods}

\subsection{Field trials}

Data from 446 field trials on winter wheat carried out in 1983-2007 in southern Sweden were used (for details of fungicides, dates etc. see Wiik, 2009; Wiik and Ewaldz, 2009). Yields measured as $\mathrm{dt} \mathrm{ha}^{-1}(\mathrm{dt}=$ metric deciton $=100 \mathrm{~kg})$ at $15 \%$ water content in untreated and fungicide-treated plots were used in the economic analyses. We chose to evaluate a single fungicide treatment just before and during heading because it had given the greatest yield 
1 plots a single fungicide treatment was applied in growth stages (GS) 45-61, i.e. from boots

2 swollen to beginning of anthesis of a crop stand according to the description of the principal

3 and secondary growth stages (00-99) by Tottman and Broad (1987). Hectolitre weight (HLW,

4 g/L), grain protein content (\%) and Hagberg falling number (s) for untreated and fungicide-

5 treated plots were not used in the evaluation of the data but are considered in the discussion.

6 The field trials were carried out on farms using different cultivars and agricultural practices,

7 e.g. fertiliser dose. All interventions except fungicide treatment were carried out by farmers.

8 The field trials, which comprised four replicates, were carried out by staff at the Rural

$9 \quad$ Economy and Agricultural Societies according to a precise protocol that included instructions on choice of field (level surface, representative of the region), choice of fungicides (most used on the market broad spectrum such as morpholines, azoles and strobilurins), timing of treatment (GS 45-61), dose (normal recommended), spraying technique (best available), harvesting etc. During 1983-1994 and 2006-2007, each entry (N, see Tables 2, 4 and 5) represents one experimental treatment in a field trial. During 1995-2005 more than one entry or experimental treatment was taken at times from a field trial, e.g. if a single fungicide treatment was tested on more than one cultivar or if there were different nitrogen levels in the same field trial. Mean is usually given as mean of years, but in some cases also as mean of entries (Tables 3 and 6). Results from the latter period are based on more entries than the earlier period.

\subsection{Study site}

The county of Scania $\left(55^{\circ} 23^{\prime}-56^{\circ} 25^{\prime} \mathrm{N}, 12^{\circ} 50^{\prime}-14^{\circ} 31^{\prime} \mathrm{E}\right)$ is the southernmost part of Sweden. Scania is a lowland area with more than $40 \%$ arable land bordered by coastline to the south, west and east. In general, slightly more than $25 \%$ of the Swedish winter wheat acreage of about 275000 ha was grown in Scania during 1983-2007 (www.sjv.se, accessed February 
1 2009). Cultural practices, cultivars used and the impact of weather are presented in earlier

2 papers (Wiik, 2009; Wiik and Ewaldz, 2009).

\section{2.3. Economics}

4 Fungicide treatment distinctly increases the costs of production by more than the obvious cost

5 of the fungicide. The economic model used was:

$6 \quad \mathrm{U}=[(\mathrm{Y}-\mathrm{D}) * \mathrm{~N}]-(\mathrm{cF}+\mathrm{cS}) \quad$ (equation 1$)$

$7 \quad \mathrm{~N}=\mathrm{Z}-(\mathrm{cP}+\mathrm{cK}+\mathrm{cH}+\mathrm{cT}+\mathrm{cA}) \quad($ equation 2$)$

8 where $\mathrm{U}\left(€ \mathrm{ha}^{-1}\right)$ is the net return (income minus costs), $\mathrm{Y}\left(\mathrm{kg} \mathrm{ha}^{-1}\right)$ is the yield increase due to

9 a fungicide treatment at GS 45-61, D $\left(\mathrm{kg} \mathrm{ha}^{-1}\right)$ is the yield loss due to wheel damage caused by spraying, $\mathrm{N}\left(€ \mathrm{~kg}^{-1}\right)$ is the net value per kg kernel, and $\mathrm{cF}\left(€ \mathrm{ha}^{-1}\right)$ and $\mathrm{cS}\left(€ \mathrm{ha}^{-1}\right)$ are the

11 costs (c) of fungicide (F) and spraying (S). The net value $\mathrm{N}$ in equation 1 is given by equation 12 2, where $\mathrm{Z}\left(€ \mathrm{~kg}^{-1}\right)$ is grain price per $\mathrm{kg}$, and $\mathrm{cP}\left(€ \mathrm{~kg}^{-1}\right)$, $\mathrm{cK}\left(€ \mathrm{~kg}^{-1}\right), \mathrm{cH}\left(€ \mathrm{~kg}^{-1}\right), \mathrm{cT}\left(€ \mathrm{~kg}^{-1}\right)$ and $\mathrm{cA}\left(€ \mathrm{~kg}^{-1}\right)$ are the costs (c) per kg kernel of phosphorus (P) losses from the field, potassium (K) losses from the field, harvest (H), transport (T) and artificial drying (A).

Cost calculations were based on data from www.agriwise.org (accessed March 2009), the Swedish Rural Economy and Agricultural Societies and the Swedish Board of Agriculture (www.sjv.se, accessed March 2009) and adjusted estimations of damage owing to fungicide application reported by Folkesson (1992). All calculations were made in Swedish crowns (SEK) and converted to euro (€) at an exchange rate of 10 SEK to $1 €$. The net return was calculated for 21 scenarios, seven scenarios each at three grain prices, 10,20 and $30 € \mathrm{dt}^{-1}$ (Table 1). In the scenarios, four different fungicide prices $\left(0,30,40\right.$ or $\left.60 € \mathrm{ha}^{-1}\right)$, three costs of spraying ( 0,6 or $12 €$ ha $\left.^{-1}\right)$ and three costs of damage owing to spraying (0, 4 or $8 €$ ha $\left.^{-1}\right)$ were used in the calculations (Table 1). Two digits designate each scenario; the first digit 1, 2 and 3 represents the grain price (10, 20 or $30 € \mathrm{dt}^{-1}$, respectively) and the second digit $0,1,2$, 
$13,4,5$ or 6 an ascending total cost of a fungicide treatment $\left(0,46,50,56,60,76\right.$ or $80 €$ ha $\left.^{-1}\right)$,

2 respectively. This means that the second digit describes the same costs in three scenarios, e.g.

3 for scenarios 13, 23 and 33 the treatment cost is $56 €$ ha $^{-1}$ but the grain price differs. One more

4 scenario (12b) was included to consider the net return of a mean optimal fungicide dose

5 during the latter period (1995-2007) of the study (optimal dose (od) = cost of fungicide at the

6 dose giving highest net return). Results from 36 field trials with different doses of Amistar

7 (two or more of $0.25 \mathrm{~L} \mathrm{ha}^{-1}, 0.50 \mathrm{~L} \mathrm{ha}^{-1}, 0.75 \mathrm{~L} \mathrm{ha}^{-1}$ and $1.00 \mathrm{~L} \mathrm{ha}^{-1}$, active ingredient

8 azoxystrobin $250 \mathrm{~g} \mathrm{~L}^{-1}$ ) carried out during 1998-2002 were used to estimate the mean optimal

9 dose (Wiik, unpublished). The functions used were based on available entries without taking

10 different varieties, nitrogen levels etc. into consideration. Fungicide resistance to strobilurins

11 had probably not evolved in Sweden at that time (Jørgensen and Thygesen, 2006). In scenario

$1212 b$, yield increase was corrected according to the dose-response found.

13 An overview of the net return is also given for the three grain prices and three fungicide 14 treatment cost levels (low, medium and high), i.e. $33 € \mathrm{ha}^{-1}, 67 € \mathrm{ha}^{-1}$ and $100 € \mathrm{ha}^{-1}$, 15 respectively (Table $2 \mathrm{a}$ and Table $2 \mathrm{~b}$ ).

The increase in harvesting costs was fixed at $0.2 € \mathrm{dt}^{-1}$, transport costs $0.5 € \mathrm{dt}^{-1}$ (30 km) and 17 drying costs $1.0 € \mathrm{dt}^{-1}$. Phosphorus (3 $\mathrm{kg} \mathrm{ton}^{-1}$ grain) and potassium (5 $\mathrm{kg} \mathrm{ton}^{-1}$ grain) were 18 removed from the field due to the grain yield increase achieved by the fungicide treatment 19 (Bertilsson et al., 2005). The resulting financial loss was estimated to be $0.6 € \mathrm{dt}^{-1}(\mathrm{P})$ and 0.3 $€ \mathrm{dt}^{-1}(\mathrm{~K})$ at fertiliser prices of $200 € \mathrm{dt}^{-1}$ and $60 € \mathrm{dt}^{-1}$, respectively. In total, the increase in 21 the costs of harvest, transport, drying and losses of $\mathrm{P}$ and $\mathrm{K}$ was estimated at $2.6 € \mathrm{dt}^{-1}$. Grain 22 price and producer price are used synonymously in the following and net return refers to the 23 producer price minus the above-mentioned costs. 


\subsection{Statistical methods}

2 ANOVA and regression (SPSS ver. 17.0) were used to analyse the results and boxplots to

3 show the variability (Hawkins, 2005). Following ANOVA, the Student-Newman-Keuls

4 (SNK-test) and Tukeys multiple range test were used to compare means.

\section{3. Results}

\subsection{Fungicide treatment and yield increase}

A mean yield increase due to a single fungicide treatment at GS 45-61 was achieved each year during the period 1983-2007 (Figure 1). In 13 years out of 25 this mean annual numerical

9 yield increase ranged between 10-19 $\mathrm{dt} \mathrm{ha}^{-1}$ and was statistically significant, but in other years the yield increase was very small, $3 \mathrm{dt} \mathrm{ha}^{-1}$ and below, and not statistically significant.

The mean annual standard deviations in yield did not differ greatly between fungicide-treated plots and untreated plots (11.9 and 11.6 respectively) (Figure 1).

\subsection{Grain price and profitability}

The variation in net return in the 771 entries during 1983-2007 was very large. For example, with a grain price of $10 € \mathrm{dt}^{-1}$ at a low fungicide treatment cost $\left(33 € \mathrm{ha}^{-1}\right.$ ), the best $10 \%$ of entries gave $113-218 € \mathrm{ha}^{-1}$ and the worst less than $-20 € \mathrm{ha}^{-1}$ (Table 2a). With the same grain price (10€ dt ${ }^{-1}$ ) and at three treatment cost levels (low, medium and high), it was profitable to treat 77,50 and $28 \%$ of the 771 entries, respectively, corresponding to a required yield increase of 4.5, 9.1 and $13.6 \mathrm{dt} \mathrm{ha}^{-1}$, respectively (Table 2b). Furthermore, at double and triple the grain price, the corresponding fraction of profitable entries obviously increased. The maximum treatment costs (calculated as means of years) while still giving a positive net return increased by a factor of about 2.3 at grain price $20 € \mathrm{dt}^{-1}$ and a factor of about 3.7 at grain price $30 € \mathrm{dt}^{-1}$ compared with grain price $10 € \mathrm{dt}^{-1}$ (Table 3). 
1 Calculated as a mean over years at the chosen three ascending grain prices the net return of a

2 single fungicide treatment at GS 45-61 was positive if the total treatment cost was less than

361,143 and $226 € \mathrm{ha}^{-1}$, respectively. Calculated as a mean over all entries it was 74, 175 and

$4275 €$ ha $^{-1}$ respectively (Table 3).

\subsection{Differences between years}

6 Net return differed substantially between years. For example, at grain price of $10 € \mathrm{dt}^{-1}$ the $^{-1}$

7 maximum treatment costs while still giving a profitable mean annual net return varied 8 between $18 € \mathrm{ha}^{-1}$ (1992) and $137 € \mathrm{ha}^{-1}$ (1987) (Table 3). The variability in net return was 9 large, not only between years but also within years (Figure 2). Three years, representing 10 different intensities of fungal disease and mean yield increases achieved by a single fungicide 11 treatment at GS 45-61, differed in the percentage of entries it was profitable to treat. At three ascending fungicide prices (low, medium and high, scenarios 11, 13 and 15) 52, 45 and 27\% respectively of the entries during 2001 were profitable to treat, while during 2002 with severe attacks of LBDs the corresponding entries were 93, 92 and 84\%, and in a year with low disease pressure (2005) only 16, 10 and 6\% (not shown in Tables or Figures).

\subsection{Costs and profitability}

Mean annual net return was negative in scenarios 15 and 16 and positive in all other scenarios (Table 4). Negative mean net returns were frequent in several years in scenarios 11-16, less

19 frequent in scenarios 21-26 and rare in scenarios 31-36. At grain price $10 € \mathrm{dt}^{-1}$ and three ascending fungicide treatment costs (scenarios 11, 13 and 16) fungicide treatment was profitable in 16, 14 and 7 years out of 25, respectively. With the same three ascending treatment costs as above and at double the grain price (scenarios 21, 23 and 26) fungicide treatment was profitable in 22, 20 and 17 years out of 25, respectively, and at triple the grain price (scenarios 31, 33 and 36) in 25, 25 and 20 years out of 25, respectively (Table 4). In 
1 scenarios 11-16 the number of profitable entries was below 50\% in 10-18 years out of 25

2 (Table 5) and no entries at all were profitable in two years, 1992 and 1994. At doubled the

3 grain price (scenarios 21-26) the number of profitable entries was below 50\% in 3-9 years out

4 of 25, while at triple the grain price (scenarios 31-36) it was below $50 \%$ in at most 4 years out 5 of 25.

\subsection{Optimal dose}

Mean maximum yield increase was achieved by using a mean dose of $0.9 \mathrm{~L} \mathrm{ha}^{-1}$ Amistar (e.g. $y=-1464 x^{2}+2658 x+13, R^{2}=0.98$, mean of four doses; $y=y i e l d$ increase, $\left.x=d o s e\right)$. However, mean maximum net return was achieved by using a mean dose of 0.55-0.66 L ha ${ }^{-1}$ Amistar (e.g. $y=-923 x^{2}+1219 x+9, R^{2}=0.93$, mean of four doses; $y=$ mean net return, $x=$ dose). In scenario 12b, when mean optimum dose and estimated yield increase were considered, the mean net return during 1995-2007 was $24 € \mathrm{ha}^{-1}$, and of these 13 years three gave a negative mean net return.

\subsection{Relationships between net return and number of profitable entries}

In each scenario, the relationship between the mean annual net returns (Table 4) and the mean annual number of profitable entries (Table 5) was strong. These relationships showed a good fit, especially at grain price $10 € \mathrm{dt}^{-1}$, with a second degree equation, e.g. scenario 11 gave the equation $y=-0.01 x^{2}+1.4 x+46.1\left(y=\right.$ no. of profitable entries and $x=$ net return, $\left.R^{2}=0.94, N=25\right)$. Profitable entries were present even in years with low mean net returns.

\subsection{Quality factors affecting payment to the farmer}

Fungicide treatment resulted in an increase in mean HLW of more than $10 \mathrm{~g} \mathrm{~L}^{-1}$ in 12 years out of 25, of which six had a statistically significant mean increase of about $20 \mathrm{~g} \mathrm{~L}^{-1}$ (Table 6). Increased HLW as a result of a single fungicide treatment at GS 45-61 positively affected payment to the farmer in $16 \%$ of the entries, i.e. when HLW exceeded $740 \mathrm{~g} \mathrm{~L}^{-1}$. In three 
1 years (1987, 2002 and 2007), HLW of $740 \mathrm{~g} \mathrm{~L}^{-1}$ was exceeded in more than one-third of the

2 entries. Fungicide treatment significantly increased HLW calculated as a mean of entries, but

3 not if calculated as a mean of years. In a mean over 18 years, protein content decreased

4 slightly ( 2\%, 10.3 to $10.1 \%$ protein content) as a result of a single fungicide treatment, but

5 the decrease was only statistically significant in one of those years. In a mean over 15 years

6 the Hagberg falling number decreased by almost $17 \%$ as a result of a single fungicide

7 treatment, of which the mean annual decrease was statistically significant in three years, with

8 the largest decrease (48 s) in 1998. The decrease in protein content and Hagberg falling

9 number due to fungicide treatment affected payment to the farmer negatively in $6 \%$ and $4 \%$ of

10 the entries, respectively, i.e. when protein content fell below $10.5 \%$ and Hagberg falling

11 number below 200 s. Fungicide treatment did significantly decrease protein content and

12 Hagberg falling number when calculated as a mean of entries, but not when calculated as a

13 mean of years.

\section{Discussion}

Doubling and tripling the grain price was the most important factor for the outcome of the net return in our calculations, especially compared with the relatively low impact of costs of fungicide application, crop harvest, transport, drying and loss of plant nutrients ( $\mathrm{P}$ and $\mathrm{K}$ ). After grain price, the cost of fungicide had the next largest impact on the net return. We consider the grain prices and costs chosen in the different scenarios to be relevant for future assessments of the profitability of fungicide input, e.g. the grain price was about $10 € \mathrm{dt}^{-1}$ up to 2006 and since then has fluctuated peaking at almost $30 € \mathrm{dt}^{-1}$ in early 2008, which is in agreement with our choice of 10, 20 and $30 € \mathrm{dt}^{-1}$. The cost of fungicide control is well in line with estimations by the National Board of Agriculture (SJV, 2008; www.agriwise.org, accessed March 2009). 
1 To examine whether fungicide application in winter wheat at GS 45-61 in southern Sweden is

2 profitable to the farmer from a strictly economic point of view, scenario 12a can be used as an example of the past and present time (SJV, 2008; www.agriwise.org, accessed March 2009).

4 The mean net return was $12 € \mathrm{ha}^{-1}$ during the 25 years of this study. This is not a conclusive 5 result, and in several years the mean net return was negative and less than $50 \%$ of the entries 6 were profitable to treat. However, changes occur over time that has an impact on the outcome. 7 The mean yield increase during 1983-1994 was $660 \mathrm{~kg} \mathrm{ha}^{-1}$ compared with $970 \mathrm{~kg} \mathrm{ha}^{-1}$ for 1995-2005, a difference probably explained by the change from azole to strobilurin fungicides (Bayles, 1999; Wiik, 2009) and to the so far effective active ingredient prothioconazole since 2005. In our chosen past and present time scenario 12a, mean annual net return was higher in the latter period compared with the earlier period, i.e. $21 € \mathrm{ha}^{-1}$ compared with $3 € \mathrm{ha}^{-1}$. In this study, we used all available entries in field trials with one single fungicide treatment in winter wheat during a limited growth period (GS 45-61), shown to be the most important GS for LBDs in Sweden (Wiik, 2009). However, in some varieties, at high infection pressure and other situations a double treatment might be needed, and the economics of more intense use also need to be evaluated. As the field trials are based on different soil types, different wheat varieties and a range of agricultural practices, our results only demonstrate a mean of the results from entries with different backgrounds and do not show the effect of different means of production, e.g. the profitability for a specific variety or at a specific nitrogen level. Such influences will be evaluated in a coming article. Consequently, changes over time in agricultural practices influence the profitability of fungicide use, such as the introduction of more active fungicides as well as fungicide resistance and fungicides more adapted to the actual disease situation. In addition, changes other than the inherent fungicidal effects can almost certainly affect the profitability of fungicide use; e.g. climate change leading to increased or decreased pesticide costs in winter wheat (Chen and McCarl, 2001), increased 
1 use of cultivars with better plant disease resistance (Priestley and Bayles, 1988; Marasas et

2 al., 2003), new diseases and disease interactions (Anderson et al., 2004; Bearchell et al.,

3 2005), new cropping systems (Duveiller et al., 2007) and price relations (Nail et al., 2007).

5 According to the Swedish recommendations a fungicide treatment is habitually required, but 6 in some years the dose can be reduced (SJV, 2008). The fungicides evaluated in the present 7 study were generally at full dose, but using results from field trials evaluating dose-response 8 we were able to consider the economic outcome of reduced doses. Many fungicides are very 9 potent and a dose reduction usually does not impair the efficacy and resulting yield increase greatly due to the non-linear shape of the dose-response curve. Wiik et al. (1995) reported 11 that half dose of Tilt Top $\left(0.5 \mathrm{~L} \mathrm{ha}^{-1}\right.$, a.i. fenpropimorph $375 \mathrm{~g} \mathrm{~L}^{-1}$ and propiconazole $125 \mathrm{~g} \mathrm{~L}^{-}$ ${ }^{1}$ ) resulted in only about $15 \%$ less yield increase, while the efficacy against LBDs, brown rust, yellow rust and mildew was 82, 90, 84 and 78\%, respectively compared with the full dose.

14 Similarly, a reduction in the dose of Amistar from $1.0 \mathrm{~L} \mathrm{ha}^{-1}$ and $0.5 \mathrm{~L} \mathrm{ha}^{-1}$ resulted in only 19\% less yield increase, and the efficacy against LBDs, brown rust, yellow rust and mildew was 85, 100, 97 and 102\%, respectively (Wiik, unpublished). With these and other results in mind it is not surprising that reduced doses are being considered in plant protection (Milne et al., 2007; Bürger et al., 2008). By using an optimum dose of Amistar (0.66 L ha' ${ }^{-1}$ ) compared with a recommended standard dose (0.8 L ha $\left.{ }^{-1}\right)$ during 1995-2007, the farmer would have gained $3 € \mathrm{ha}^{-1}$ (24 instead of $21 € \mathrm{ha}^{-1}$ ) according to our calculations.

Scenario 25 may describe a most likely possible future, a scenario with double the producer price compared with scenarios $10-16$ and a 52\% increase in the costs owing to fungicide use compared with our past and present time scenario 12a. The mean net return of this scenario 
1 during all 25 years was $65 € \mathrm{ha}^{-1}$. However, divided into the earlier and later periods

2 mentioned previously, both the net return and the percentage of profitable entries were higher

3 in the later period than in the earlier period, i.e. $86 € \mathrm{ha}^{-1}$ compared with $43 € \mathrm{ha}^{-1}$ and $78 \%$

4 compared with 58\%, respectively. In another scenario, scenario 16 , with the same low grain

5 price as in the past and present time scenario 12a but with a $60 \%$ increase in the cost of

6 fungicide use, the mean net return during the 25 years of study was negative (a loss of $16 €$

$7 \mathrm{ha}^{-1}$ ) and only $30 \%$ of the entries were profitable to treat with a fungicide.

9 The Official Statistics of Sweden (SCB/SJV, 2008; Agneta Sundgren, pers. comm., 2009) show that fungicides with active ingredients such as prothioconazole, pyraclostrobin, 11 propiconazole, azoxystrobin, fenpropimorph and cyprodinil were used on 99\% of the winter

wheat acreage in southern Sweden during 2006. However, the present study shows that a routine single fungicide input at GS 45-61 against LBDs in southern Sweden was questionable from a strictly farm economics point of view in almost one-third of the entries during 1995-2007, and probably higher in central Sweden (Wiik, 1991). On the other hand, part of the total accumulated profit of $328 € \mathrm{ha}^{-1}$ to $198 € \mathrm{ha}^{-1}$ (scenarios 11-13) in southern Sweden during 1995-2007 would be somewhat at risk unless entirely reliable decision support systems are available. Accordingly, thorough economic analyses and probabilities must be allowed to play a vital part in decision support systems (Headley and Lewis, 1967; Rossing et al., 1994; Fabre et al., 2007). No true decision support system is in use for LBDs in Sweden. Although existing recommendations take account of precipitation, infection pressure, fungicide, fungicide dose, soil type and cultivar, fungicides against LBDs are used almost routinely in southern Sweden (SJV, 2008). 
1 In this study, grain type (bread, starch or feed), HLW, protein content and Hagberg falling

2 number and some other factors upon which producer price were not used in the economic

3 calculations because they have not been routinely recorded. Whether the farmer aimed at

4 bread or feed grain is not unimportant, but the producer price difference was only about $7 \%$

5 higher for bread grain in costing calculations 2000-2008 (www.agriwise.org, accessed March

6 2009). Fungicide treatment affected HLW positively and in exceptional years protein content

7 and Hagberg falling number negatively, but probably without major economic consequences

8 to the farmer, even if weather and choice of cultivar can be decisive (Ruske et al., 2004;

9 Gooding, 2007; Wang et al., 2008). Nitrogen fertilisation affects yield, quality parameters and the yield increase achieved by fungicide treatment (Dimmock and Gooding, 2002; Walters and Bingham, 2007). For example, in Swedish field trials carried out during 2001-2003 a single fungicide treatment during heading of winter wheat cultivar Ritmo at three fertiliser 13 levels of 120, 170 and $220 \mathrm{~kg} \mathrm{~N}^{-1}$ gave yield increases of 10.6, 12.6 and $16.1 \mathrm{dt} \mathrm{ha}^{-1}$ and improved kernel protein content from 9.9 to 10.8 and 11.7 \%, respectively (Wiik and Pålsson, 2004). In the present study, which did not permit direct comparisons between nitrogen levels, the range of nitrogen fertilisation was $84-230 \mathrm{~kg} \mathrm{~N} \mathrm{ha}^{-1}$. The protein content in our study changed due to amount of nitrogen fertilisation, as in the study by Wiik and Pålsson (2004), with the yield increase due to a single fungicide treatment being statistically significant between nitrogen levels at high amounts of nitrogen fertilization ( $>180 \mathrm{~kg} \mathrm{~N}^{-1}$ ). About 20\% of the field trials in our study were fertilised with more than $180 \mathrm{~kg} \mathrm{~N} \mathrm{ha}^{-1}$ and thus nitrogen fertilisation will influence the net return, but we omitted the most likely influence of nitrogen from the present economic analysis.

For decades, fungicides have been an important means of production in winter wheat in many countries and unfortunately or fortunately not just an optional extra (Eyal, 1981; Cooper and 
1 Dobson, 2007). Our calculations were carried out from a strict farm production economics

2 perspective but as fungicides may have adverse effects on the environment and human health,

3 approval based on risk-benefit analysis has long been regulated by public authorities (Headley

4 and Lewis, 1967). The economics of pesticide usage are complex and influenced by market

5 prices and involvement from the authorities (Zilberman et al., 1991; Serra et al., 2005). Taxes

6 on pesticides instead of bans may better fulfil environmental goals (Zilberman et al., 1991)

7 and reduced price support or a decreased producer price will impede the use of pesticides

8 (Serra et al., 2005). Regev et al. (1997) showed that fungicides were not risk-reducing at low

9 levels of rainfall and we found no evidence of lower crop variability in fungicide-treated plots than in untreated plots. Subsequently, fungicides did not increase cropping reliability, a fact that is also noteworthy in an economic perspective. In the different scenarios we indirectly

12 showed the effect of market change through the different grain prices selected, and the effects of taxes on pesticides and fuel through the different costs of production. Changes are difficult to predict but scenarios like ours based on real facts are valuable as a baseline for future discussions and recommendations.

The profitability to farmers of using a single fungicide treatment in winter wheat in southernmost Sweden during 1983-2007 was found to be doubtful rather often, although it improved during the latter part of the study due to more effective fungicides becoming available. Producer price and different costs obviously influenced the farm profits.

21 Manageable and non-manageable changes and variations within and between years highlights

22 the need for valid, economically sound and risk/uncertainty-derived decision support systems, 23 preferably based on a more holistic concept than those of today. 


\section{Acknowledgements}

2 The Swedish Farmers' Foundation for Agricultural Research (SLF), the Swedish Board of

3 Agriculture and the Swedish University of Agricultural Sciences funded this research. Field

4 trials were carried out by the Agricultural Societies in southern Sweden. Our sincere thanks

5 for creative discussions and critical reviews of this paper go to: Eva Johansson, Erland

6 Liljeroth, Arnulf Merker, and Hans Andersson, Jan-Eric Englund, Göran Gustafsson, Lennart

7 Johnsson, Mary McAfee and Gunnar Svensson.

8

9

10

11

12

13

14

15

16

17

18

19

20

21

22

23

24

25

\section{References}

Anderson, P.K., Cunningham, A.A., Patel, N.G., Morales, F.J., Epstein, P.R., Daszak, P., 2004. Emerging infectious diseases of plants: pathogen pollution, climate change and agrotechnology drivers. TRENDS in Ecology and Evolution 19 (10), 535-544.

Bayles, R., 1999. The interaction of strobilurin fungicides with cereal varieties. Plant Var. Seeds 12 (2), 129-140.

Bearchell, S.J., Fraaije, B.A., Shaw, M.W., Fitt, B.D.L., 2005. Wheat archive links long-term fungal pathogen population dynamics to air pollution. PNAS 102, 5438-5442.

Bertilsson, G., Rosenqvist, H., Mattsson, L., 2005. Fosforgödsling och odlingsekonomi med perspektiv på miljömål. Naturvårsdsverket, Rapport 5518, 58 p. Stockholm.

Bürger, J., de Mol, F., Gerowitt, B., 2008. The "necessary extent" of pesticide use - Thoughts about a key term in German pesticide policy. Crop Prot. 27, 343-351. 
1 Carlson, G.A., Main, C.E., 1976. Economics of disease-loss management. Annual Review of

2 Phytopathol. 14, 381-403.

3

4 Chen, C-C., McCarl, B.A., 2001. An investigation of the relationship between pesticide usage 5 and climate change. Climatic change 50, 475-487.

6

7 Cook, R.J., Jenkins, J.E.E., 1988. The contribution and value of pesticides to disease control

8 in cereals. In Control of plant diseases: Costs and Benefits (eds. Clifford BC, Lester E), 3-12. 9

Cook, R.J., King, J.E., 1984. Loss caused by cereal diseases and the economics of fungicidal control. In Plant Diseases: Infection, Damage and Loss, 237-245. Blackwell Scientifique Publications, Oxford.

Cooper, J., Dobson, H., 2007. The benefits of pesticides to mankind and the environment. Crop Prot. 26, 1337-1348.

16

Dimmock, J.P.R.E., Gooding, M.J., 2002. The influence of foliar diseases, and their control by fungicides, on the protein concentration in wheat grain: a review. J. Agric. Sci. 138, 349366.

Duveiller, E., Singh, R.P., Nicol, J.M., 2007. The challenges of maintaining wheat productivity: pests, diseases, and potential epidemics. Euphytica 157, 417-430. 
1 Fabre, F., Plantegenest, M., Yuen, J., 2007. Financial benefit of using crop protection decision

2 rules over systematic spraying strategies. Phytopathol. 97, 1484-1490.

3

4 Folkesson, Ö., 1992. Körskador vid körning i växande gröda. Faktablad om växtskydd,

5 Jordbruk 65 J, 4 p. SLU Uppsala.

6

7 Gooding MJ., 2007. Influence of foliar diseases and their control by fungicides on grain yield

8 and quality in wheat. In: H.T. Buck et al. (eds.) Wheat Production in Stressed Environments,

9 567-581. Developments in Plant Breeding vol. 12. Springer.

Hawkins, D., 2005. Biomeasurement. Understanding, Analysing, and Communicating Data in the Biosciences. 284 p. Oxford University Press, UK.

Headley, J.C., Lewis, J.N., 1967. The pesticide problem: an economic approach to public policy, pp. 141. Resources for the Future, Inc., Washington, D.C., USA.

Jørgensen, L.N., Thygesen, K. 2006. Fungicide resistance and its impact on recommendations to farmers - experience from Denmark. In Aspects of Appl. Biol. 71, 65-70.

KSLA, 1989. Minskad bekämpning i jordbruket. Möjligheter och konsekvenser. Rapport nr.

36, pp. 88. Kungl. Skogs- och Lantbruksakademien, Stockholm Sweden (ISSN 0349-1811).

23 Marasas, C.N., Smale, M., Singh, R.P., 2003. The economic impact of productivity

24 maintenance research: breeding for leaf rust resistance in modern wheat. Agric. Econ. 29, $25 \quad 253-263$. 
2 Milne, A, Paveley, N., Audsley, E., Parsons, D., 2007. A model of the effect of fungicides on

3 disease-induced yield loss, for use in wheat disease management decision support systems.

$4 \quad$ Ann. Appl. Biol. 151, 113-125.

5

6 Nail, E.L., Young, D.L., Schillinger, W.F., 2007. Diesel and glyphosate price changes benefit

7 the economics of conservation tillage versus traditional tillage. Soil \& Tillage Research 94, $8 \quad 321-327$.

9

Ordish, G., Dufour, D., 1969. Economic bases for protection against plant diseases. Annu.

11 Rev. Phytopathol. 7, 31-50.

12

13 Priestley, R.H., Bayles, R.A., 1988. The contribution and value of resistant cultivars to

14 disease control in cereals. In: Control of Plant Diseases: Costs and Benefits, Clifford BC and

15 Lester, E. eds., 53-65.

16

17 Regev, U., Gotsch, N., Rieder, P., 1997. Are fungicides, nitrogen and plant growth regulators 18 risk-reducing? Empirical evidence from Swiss wheat production. J. Agric. Econ. 48, 167-178.

20 Rossing, W.A.H., Daamen, R.A., Hendrix, E.M.T., 1994. Framework to support decisions on

21 chemical pest control under uncertainty, applied to aphids and brown rust in winter wheat.

22 Crop Prot. 13 (1), 25-34. 
1 Ruske, R.E., Gooding, M.J., Dobraszczyk, B.J., 2004. Effects of triazole and strobilurin

2 fungicide programmes, with and without late-season nitrogen fertiliser, on the baking quality

3 of Malacca winter wheat. J. Cereal Sci. 40, 1-8.

4

SCB/SJV, 2008. Växtskyddsmedel i jord och trädgårdsbruket 2006. Statistiska Meddelanden MI 31 SM 0701 korrigerad version, 70 p. (www.sjv.se and www.scb.se accessed March

7 2009).

8

9 Serra, T., Zilberman, D., Goodwin, B.K., Hyvonen, K., 2005. Replacement of agricultural price supports by area payments in the European Union and the effects on pesticide use. Am. J. Agric. Econ. 87, 870-884.

12

SJV, 2008. Bekämpningsrekommendationer. Svampar och insekter 2008 (www.sjv.se, accessed March 2009).

Sundell, B., 1980. Växtskadegörare i jordbruket. 3. Ekonomiska effekter av en minskad användning av kemiska bekämpningsmedel (engl. summary). Rapport från institutionen för ekonomi och statistik, 170, pp. 128. SLU Uppsala.

Tottman, D.R., Broad, H., 1987. The decimal code for the growth stages of cereals, with illustrations. Ann. appl. Biol. 110, 441-454.

Walters, D.R., Bingham, I.J., 2007. Influence of nutrition on disease development caused by fungal pathogens: implications for plant disease control. Ann. appl. Biol. 151, 307-324. 
1 Wang, J., Pawelzik,E., Weinert, J, Zhao, Q, Wolf, G.A., 2008. Factors influencing falling

2 number in winter wheat. Eur. Food Res. Technol. 226, 1365-1371.

3

4 Wiik, L., 1991. Ekonomisk betydelse av svampsjukdomar i stråsäd vid förändrade priser

5 (Engl. summary). 32:a svenska växtskyddskonferensen. Uppsala 30-31 januari 1991.

$6 \quad$ Skadedjur och växtsjukdomar, 171-186.

7

8 Wiik, L., 2009. Yield and disease control in winter wheat in southern Sweden during 1977-

9 2005. Crop Prot. 28, 82-89.

10

11 Wiik, L., Ewaldz, T. Impact of temperature and precipitation on yield and plant diseases of

12 winter wheat in southern Sweden 1983-2007, Crop Protection (2009),

doi:10.1016/j.cropro.2009.05.002.

14

Wiik, L., Pålsson, L., 2004. Olika insatser av fungicider och kväve i höstvete. Skåneförsök 2003. Meddelande nr 70, försöksringarna och hushållningssällskapen i Skåne, 144-161.

17

Wiik, L., Olofsson, B., Johnsson, L., Olvång, H., 1995. Sprutning mot skadesvampar i stråsäd med fungicider 1976-1992. Engl. summary. SLU, institutionen för växtskyddsvetenskap, rapport 3, pp. 115.

21

Zadoks, J.C., 1984. Analyzing cost effectiveness of EPIPRE. EPPO Bull. 14, 401-407.

24 Zilberman, D., Schmitz, A, Casterline, G., Lichtenberg, E., Stebert, J.B., 1991. The

25 economics of pesticide use and regulation. Science 253, 518-522. 
Table 1. Designation and economics of 22 scenarios with different grain prices $\left(€ \mathrm{dt}^{-1}\right)$ to the farmer and different treatment costs associated with spraying $\left(€ \mathrm{ha}^{-1}\right)$

\begin{tabular}{|c|c|c|c|c|c|c|}
\hline \multicolumn{3}{|c|}{$\begin{array}{c}\text { Designation of scenarios at three } \\
\text { grain prices }\end{array}$} & \multirow{2}{*}{$\begin{array}{c}\text { Fungicide price } \\
€ \mathrm{ha}^{-1}\end{array}$} & \multirow{2}{*}{$\begin{array}{c}\text { Cost of spraying } \\
€ \mathrm{ha}^{-1}\end{array}$} & \multirow{2}{*}{$\begin{array}{c}\sim \text { Cost of damage } \\
€^{\mathrm{a}} \\
\mathrm{ha}^{-1}\end{array}$} & \multirow{2}{*}{$\begin{array}{c}\text { Treatment cost } \\
€ \mathrm{ha}^{-1}\end{array}$} \\
\hline $10 € \mathrm{dt}^{-1}$ & $20 € \mathrm{dt}^{-1}$ & $30 € \mathrm{dt}^{-1}$ & & & & \\
\hline 10 & 20 & 30 & 0 & 0 & 0 & - \\
\hline 11 & 21 & 31 & 30 & 12 & 4 & 46 \\
\hline $12 \mathrm{a}$ & 22 & 32 & 40 & 6 & 4 & 50 \\
\hline $12 b$ & - & - & od $^{b}$ & 6 & 4 & $\mathrm{od}^{\mathrm{b}}$ \\
\hline 13 & 23 & 33 & 40 & 12 & 4 & 56 \\
\hline 14 & 24 & 34 & 40 & 12 & 8 & 60 \\
\hline 15 & 25 & 35 & 60 & 12 & 4 & 76 \\
\hline 16 & 26 & 36 & 60 & 12 & 8 & 80 \\
\hline
\end{tabular}

${ }^{\mathrm{a}}$ Mean cost at $0.4 \%$ damage in the crop due to spraying was $\sim 4 € \mathrm{ha}^{-1}$, and at $0.8 \% \sim 8 € \mathrm{ha}^{-1}$ depending on yield level.

${ }^{\mathrm{b}}$ In scenario $12 \mathrm{~b}$, the cost of Amistar at optimal dose (od) was included to consider the net return when a mean optimal fungicide dose was used during the latter period of the evaluation period (1995-2007). 
Table 3. Maximum total cost $\left(€ \mathrm{ha}^{-1}\right)$ of a single fungicide treatment at GS 45-61 in southern Sweden 1983-2007 that still gives a profitable net return at three grain prices (scenarios 10,20 and 30)

\begin{tabular}{|c|c|c|c|c|c|c|c|}
\hline \multirow[t]{2}{*}{ Year $\left(\mathrm{N}^{\mathrm{a}}\right)$} & \multicolumn{2}{|c|}{ Grain price $10 € \mathrm{dt}^{-1}$} & \multicolumn{2}{|c|}{ Grain price $20 € \mathrm{dt}^{-1}$} & \multicolumn{2}{|c|}{ Grain price $30 € \mathrm{dt}^{-1}$} & \multirow[t]{2}{*}{ Tukey $^{\mathrm{a}}$} \\
\hline & Max. cost & Std. dev. & Max. cost & Std. dev & Max. cost & Std. dev & \\
\hline 1983 (13) & 46 & 28 & 109 & 66 & 172 & 104 & cdef \\
\hline $1985 \quad(13)$ & 32 & 18 & 76 & 42 & 120 & 66 & def \\
\hline 1986 & 34 & 44 & 80 & 103 & 126 & 162 & def \\
\hline $1987 \quad(7)$ & 137 & 41 & 323 & 97 & 508 & 153 & $\mathrm{a}$ \\
\hline 1989 (12) & 19 & 24 & 44 & 57 & 70 & 89 & $\mathrm{f}$ \\
\hline 1990 & 95 & 51 & 224 & 119 & 353 & 187 & $a b c$ \\
\hline 1991 (11) & 64 & 23 & 150 & 53 & 237 & 83 & cdef \\
\hline 1992 & 18 & 11 & 43 & 26 & 67 & 41 & $\mathrm{f}$ \\
\hline 1993 & 24 & 24 & 56 & 56 & 89 & 88 & ef \\
\hline $1998 \quad(36)$ & 101 & 41 & 237 & 95 & 374 & 150 & $\mathrm{abc}$ \\
\hline 1999 (34) & 90 & 46 & 211 & 109 & 332 & 172 & abcd \\
\hline $2000 \quad(37)$ & 58 & 33 & 137 & 79 & 215 & 124 & cdef \\
\hline $2001 \quad$ (93) & 53 & 41 & 124 & 95 & 195 & 150 & cdef \\
\hline 2002 (107) & 132 & 54 & 311 & 127 & 490 & 201 & $\mathrm{ab}$ \\
\hline 2003 (94) & 81 & 30 & 191 & 71 & 301 & 111 & abcde \\
\hline $2004 \quad(36)$ & 67 & 42 & 158 & 99 & 249 & 155 & cdef \\
\hline $2005 \quad(31)$ & 24 & 25 & 57 & 59 & 91 & 92 & ef \\
\hline 2006 & 36 & 19 & 84 & 45 & 132 & 70 & def \\
\hline 2007 & 72 & 24 & 169 & 55 & 266 & 87 & cdef \\
\hline
\end{tabular}

${ }^{a}$ Valid in max. cost columns at all three grain prices. Group size is unequal. Harmonic mean of group sizes is used.

Type I error levels are not guaranteed. ${ }^{\mathrm{b}}$ Mean of years $(\mathrm{N}=25) .{ }^{\mathrm{c}}$ Mean of all entries $(\mathrm{N}=771)$. 


\section{$\mathrm{U} 3 / \mathrm{Tab}$}

Table 4. Different scenarios and mean annual profitability $\left(€ \mathrm{ha}^{-1}\right)$ for a single fungicide treatment at GS 45-61 in southern Sweden $1983-2007$.

Shaded areas represent annual means with negative profitability

\begin{tabular}{|c|c|c|c|c|c|c|c|c|c|c|c|c|c|c|c|c|c|c|}
\hline \multirow[t]{2}{*}{ Year } & \multicolumn{18}{|c|}{ Net return $\left(€\right.$ ha $\left.^{-1}\right)$, annual mean $1983-2007$ of 18 scenarios } \\
\hline & 11 & $12 \mathrm{a}$ & 13 & 14 & 15 & 16 & 21 & 22 & 23 & 24 & 25 & 26 & 31 & 32 & 33 & 34 & 35 & 36 \\
\hline 1983 & 3 & -1 & -7 & -9 & -27 & -29 & 63 & 59 & 53 & 49 & 33 & 29 & 123 & 119 & 113 & 107 & 93 & 87 \\
\hline 1984 & 16 & 12 & 6 & 3 & -14 & -17 & 93 & 89 & 83 & 78 & 63 & 58 & 171 & 167 & 161 & 153 & 141 & 133 \\
\hline 1985 & -12 & -16 & -22 & -24 & -42 & -44 & 29 & 25 & 19 & 14 & -1 & -6 & 70 & 66 & 60 & 52 & 40 & 32 \\
\hline 1986 & -10 & -14 & -20 & -22 & -40 & -42 & 33 & 29 & 23 & 17 & 3 & -3 & 76 & 72 & 66 & 57 & 46 & 37 \\
\hline 1987 & 93 & 89 & 83 & 82 & 63 & 62 & 276 & 272 & 266 & 262 & 246 & 242 & 459 & 455 & 449 & 443 & 429 & 423 \\
\hline 1988 & 17 & 13 & 7 & 5 & -13 & -15 & 98 & 94 & 88 & 82 & 68 & 62 & 178 & 174 & 168 & 159 & 148 & 139 \\
\hline 1989 & -25 & -29 & -35 & -37 & -55 & -57 & -3 & -7 & -13 & -17 & -33 & -37 & 20 & 16 & 10 & 3 & -10 & -17 \\
\hline 1990 & 51 & 47 & 41 & 38 & 21 & 18 & 176 & 172 & 166 & 160 & 146 & 140 & 301 & 297 & 291 & 281 & 271 & 261 \\
\hline 1991 & 20 & 16 & 10 & 7 & -10 & -13 & 103 & 99 & 93 & 88 & 73 & 68 & 187 & 183 & 177 & 168 & 157 & 148 \\
\hline 1992 & -26 & -30 & -36 & -38 & -56 & -58 & -4 & -8 & -14 & -19 & -34 & -39 & 18 & 14 & 8 & 0 & -12 & -20 \\
\hline 1993 & -20 & -24 & -30 & -33 & -50 & -53 & 9 & 5 & -1 & -7 & -21 & -27 & 38 & 34 & 28 & 19 & 8 & -1 \\
\hline 1994 & -25 & -29 & -35 & -37 & -55 & -57 & -1 & -5 & -11 & -16 & -31 & -36 & 22 & 18 & 12 & 4 & -8 & -16 \\
\hline 1995 & -9 & -13 & -19 & -21 & -39 & -41 & 36 & 32 & 26 & 20 & 6 & 0 & 81 & 77 & 71 & 62 & 51 & 42 \\
\hline 1996 & 30 & 26 & 20 & 17 & 0 & -3 & 127 & 123 & 117 & 111 & 97 & 91 & 220 & 221 & 215 & 205 & 195 & 185 \\
\hline 1997 & 43 & 39 & 33 & 30 & 13 & 10 & 157 & 153 & 147 & 141 & 127 & 121 & 272 & 268 & 262 & 251 & 242 & 231 \\
\hline 1998 & 56 & 52 & 46 & 43 & 26 & 23 & 189 & 185 & 179 & 172 & 159 & 152 & 321 & 317 & 311 & 300 & 291 & 280 \\
\hline 1999 & 45 & 41 & 35 & 32 & 15 & 12 & 162 & 158 & 152 & 145 & 132 & 125 & 279 & 275 & 269 & 258 & 249 & 238 \\
\hline 2000 & 13 & 9 & 3 & 0 & -17 & -20 & 87 & 83 & 77 & 70 & 57 & 50 & 162 & 158 & 152 & 140 & 132 & 120 \\
\hline 2001 & 8 & 4 & -2 & -5 & -22 & -25 & 75 & 71 & 65 & 58 & 45 & 38 & 142 & 138 & 132 & 120 & 112 & 100 \\
\hline 2002 & 87 & 83 & 77 & 74 & 57 & 54 & 262 & 258 & 252 & 245 & 232 & 225 & 437 & 433 & 427 & 415 & 407 & 395 \\
\hline 2003 & 36 & 3 & 26 & 23 & 6 & 3 & 142 & 138 & 132 & 125 & 112 & 105 & 248 & 244 & 238 & 227 & 218 & 207 \\
\hline 2004 & 22 & 18 & 12 & 9 & -8 & -11 & 109 & 105 & 99 & 91 & 79 & 71 & 195 & 191 & 185 & 174 & 165 & 154 \\
\hline 2005 & -21 & -25 & -31 & -35 & -5 & -55 & 7 & 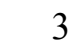 & -3 & -11 & -23 & -31 & 35 & 31 & 25 & 12 & 5 & -8 \\
\hline 2006 & -9 & -13 & -19 & -22 & -39 & -42 & 36 & 32 & 26 & 19 & 6 & -1 & 80 & 76 & 70 & 60 & 50 & 40 \\
\hline 2007 & 27 & 23 & 17 & 14 & -3 & -6 & 121 & 117 & 111 & 104 & 91 & 84 & 214 & 210 & 204 & 194 & 184 & 174 \\
\hline Mean $^{a}$ & 16 & 12 & 6 & 4 & -14 & -16 & 95 & 91 & 85 & 79 & 65 & 59 & 174 & 170 & 164 & 155 & 144 & 135 \\
\hline
\end{tabular}

${ }^{\mathrm{a}}$ Mean of years. 


\section{$\mathrm{U} 3 / \mathrm{Tab}$}

Table 5. Profitability (\% of no. of entries) of a single fungicide treatment at GS 45-61 in southern Sweden 1983-2007. Shaded areas represent annual means with negative profitability in Table 3

\begin{tabular}{|c|c|c|c|c|c|c|c|c|c|c|c|c|c|c|c|c|c|c|c|}
\hline \multirow[t]{2}{*}{ Year } & \multirow[t]{2}{*}{$\mathrm{N}$} & \multicolumn{18}{|c|}{ Profitable entries (\%), annual mean of 18 scenarios $1983-2007$} \\
\hline & & 11 & $12 \mathrm{a}$ & 13 & 14 & 15 & 16 & 21 & 22 & 23 & 24 & 25 & 26 & 31 & 32 & 33 & 34 & 35 & 36 \\
\hline 1983 & 13 & 46 & 46 & 38 & 38 & 15 & 15 & 85 & 85 & 77 & 77 & 69 & 62 & 85 & 85 & 85 & 85 & 85 & 77 \\
\hline 1984 & 16 & 75 & 75 & 75 & 69 & 25 & 25 & 100 & 94 & 94 & 94 & 75 & 75 & 100 & 100 & 100 & 100 & 94 & 94 \\
\hline 1985 & 13 & 15 & 15 & 8 & 8 & 0 & 0 & 85 & 77 & 62 & 62 & 46 & 38 & 92 & 92 & 92 & 92 & 77 & 62 \\
\hline 1986 & 7 & 29 & 29 & 29 & 14 & 14 & 14 & 57 & 57 & 57 & 57 & 43 & 29 & 57 & 57 & 57 & 57 & 57 & 57 \\
\hline 1987 & 7 & 100 & 100 & 100 & 100 & 86 & 86 & 100 & 100 & 100 & 100 & 100 & 100 & 100 & 100 & 100 & 100 & 100 & 100 \\
\hline 1988 & 5 & 80 & 80 & 80 & 80 & 0 & 0 & 100 & 100 & 100 & 100 & 100 & 100 & 100 & 100 & 100 & 100 & 100 & 100 \\
\hline 1989 & 12 & 8 & 8 & 8 & 8 & 8 & 8 & 42 & 33 & 33 & 25 & 25 & 17 & 42 & 42 & 42 & 42 & 33 & 33 \\
\hline 1990 & 9 & 89 & 89 & 89 & 78 & 67 & 67 & 89 & 89 & 89 & 89 & 89 & 89 & 89 & 89 & 89 & 89 & 89 & 89 \\
\hline 1991 & 11 & 82 & 73 & 64 & 64 & 36 & 36 & 100 & 100 & 100 & 100 & 100 & 91 & 100 & 100 & 100 & 100 & 100 & 100 \\
\hline 1992 & 6 & 0 & 0 & 0 & 0 & 0 & 0 & 50 & 50 & 33 & 33 & 0 & 0 & 83 & 50 & 50 & 50 & 50 & 50 \\
\hline 1993 & 3 & 33 & 33 & 0 & 0 & 0 & 0 & 67 & 33 & 33 & 33 & 33 & 33 & 67 & 67 & 67 & 67 & 33 & 33 \\
\hline 1994 & 12 & 0 & 0 & 0 & 0 & 0 & 0 & 42 & 42 & 33 & 33 & 17 & 8 & 75 & 58 & 50 & 42 & 42 & 42 \\
\hline 1995 & 47 & 32 & 26 & 19 & 17 & 6 & 6 & 68 & 68 & 64 & 62 & 51 & 40 & 81 & 79 & 79 & 72 & 68 & 62 \\
\hline 1996 & 65 & 74 & 71 & 66 & 66 & 52 & 48 & 82 & 80 & 78 & 78 & 77 & 74 & 83 & 83 & 83 & 82 & 80 & 78 \\
\hline 1997 & 63 & 86 & 84 & 79 & 78 & 57 & 54 & 97 & 97 & 95 & 95 & 95 & 94 & 98 & 98 & 98 & 97 & 97 & 95 \\
\hline 1998 & 36 & 94 & 94 & 92 & 89 & 67 & 64 & 100 & 100 & 100 & 97 & 97 & 97 & 100 & 100 & 100 & 100 & 100 & 100 \\
\hline 1999 & 34 & 85 & 79 & 71 & 68 & 56 & 56 & 97 & 97 & 97 & 94 & 94 & 91 & 97 & 97 & 97 & 97 & 97 & 97 \\
\hline 2000 & 37 & 62 & 62 & 57 & 51 & 30 & 27 & 86 & 86 & 78 & 78 & 76 & 76 & 89 & 89 & 89 & 89 & 86 & 78 \\
\hline 2001 & 93 & 52 & 48 & 45 & 43 & 27 & 26 & 74 & 74 & 74 & 71 & 66 & 60 & 78 & 77 & 75 & 74 & 74 & 73 \\
\hline 2002 & 107 & 93 & 92 & 92 & 92 & 84 & 84 & 98 & 98 & 97 & 96 & 93 & 93 & 100 & 100 & 99 & 98 & 98 & 97 \\
\hline 2003 & 94 & 87 & 83 & 76 & 73 & 55 & 53 & 100 & 100 & 99 & 98 & 95 & 94 & 100 & 100 & 100 & 100 & 100 & 98 \\
\hline 2004 & 36 & 67 & 61 & 58 & 58 & 42 & 39 & 83 & 83 & 81 & 81 & 72 & 69 & 89 & 83 & 83 & 83 & 83 & 81 \\
\hline 2005 & 31 & 16 & 13 & 10 & 10 & 6 & 6 & 42 & 39 & 32 & 32 & 29 & 26 & 55 & 55 & 48 & 42 & 39 & 32 \\
\hline 2006 & 6 & 17 & 17 & 17 & 17 & 0 & 0 & 83 & 83 & 83 & 83 & 67 & 33 & 83 & 83 & 83 & 83 & 83 & 83 \\
\hline 2007 & 8 & 88 & 75 & 75 & 75 & 50 & 25 & 100 & 100 & 100 & 100 & 100 & 100 & 100 & 100 & 100 & 100 & 100 & 100 \\
\hline Mean $^{a}$ & & 56 & 54 & 50 & 48 & 31 & 30 & 81 & 79 & 76 & 75 & 68 & 64 & 86 & 83 & 83 & 82 & 79 & 76 \\
\hline
\end{tabular}

${ }^{\mathrm{a}}$ Mean of years. 
Table 6. Influence of fungicide treatment on wheat grain factors (HLW, protein content, Hagberg falling number) that affect the price received by the farmer. Calculated change between fungicide-treated and untreated field plots deriving from payment threshold values (see footnote d)

\begin{tabular}{|c|c|c|c|c|c|c|c|c|c|c|c|c|}
\hline \multirow[t]{2}{*}{ Year } & \multirow[b]{2}{*}{$\mathrm{N}^{\mathrm{a}}$} & \multicolumn{3}{|c|}{ HLW g/L } & \multicolumn{5}{|c|}{ Protein content $\%$} & \multicolumn{3}{|c|}{ Hagberg falling number $\mathrm{s}$} \\
\hline & & Untreat $^{\mathrm{b}}$ & Treat $^{\mathrm{c}}$ & Change $\%$ & $\mathrm{~N}^{\mathrm{a}}$ & Untreat $^{\mathrm{b}}$ & Treat $^{\mathrm{c}}$ & Change $\%$ & $\mathrm{~N}^{\mathrm{a}}$ & Untreat $^{\mathrm{b}}$ & Treat $^{\mathrm{c}}$ & Change ${ }^{\mathrm{d}} \%$ \\
\hline 1983 & 13 & 785 & 798 & 0 & - & - & - & - & - & - & - & - \\
\hline 1984 & 16 & 789 & 800 & 6 & - & - & - & - & - & - & - & - \\
\hline 1985 & 13 & 809 & 808 & 0 & - & - & - & - & - & - & - & - \\
\hline 1986 & 7 & 821 & 820 & 0 & - & - & - & - & - & - & - & - \\
\hline 1987 & 7 & 754 & 777 & 57 & - & - & - & - & - & - & - & - \\
\hline 1988 & 5 & 826 & 832 & 0 & - & - & - & - & - & - & - & - \\
\hline 1989 & 12 & 829 & 829 & 0 & 7 & 11.8 & 12.0 & 0 & 7 & 264 & 260 & 0 \\
\hline 1990 & 9 & 831 & 833 & 0 & 4 & 10.3 & 10.7 & 0 & 4 & 270 & 270 & 0 \\
\hline 1991 & 11 & 820 & 824 & 0 & 8 & 10.6 & 10.6 & 0 & 10 & 270 & 270 & 0 \\
\hline 1992 & 6 & 827 & 825 & 0 & 3 & 10.7 & 10.8 & 0 & 3 & 270 & 270 & 0 \\
\hline 1993 & 3 & 821 & 823 & 0 & - & - & - & - & 3 & 270 & 270 & 0 \\
\hline 1994 & 10 & 828 & 827 & 0 & 2 & 12.4 & 12.1 & 0 & - & - & - & - \\
\hline 1995 & 41 & 782 & 788 & 0 & 3 & 10.8 & 10.5 & 67 & - & - & - & - \\
\hline 1996 & 65 & 743 & $759 *$ & 20 & 56 & 10.6 & 10.3 & 9 & - & - & - & - \\
\hline 1997 & 49 & 770 & $787 * *$ & 8 & 28 & 10.9 & 10.5 & 0 & - & - & - & - \\
\hline 1998 & 36 & 753 & 768 & 22 & 36 & 11.7 & 11.3 & 6 & 36 & 329 & $288^{*}$ & 22 \\
\hline 1999 & 34 & 710 & 729 & 15 & 32 & 11.1 & 10.7 & 13 & 32 & 181 & 167 & 6 \\
\hline 2000 & 36 & 716 & 721 & 0 & 35 & 12.0 & 11.9 & 3 & 35 & 254 & 240 & 17 \\
\hline 2001 & 71 & 760 & $770 * *$ & 17 & 72 & 10.9 & 10.8 & 1 & 68 & 323 & $304 *$ & 4 \\
\hline 2002 & 98 & 726 & $764 * * *$ & 36 & 98 & 11.4 & $10.9 * * *$ & 10 & 71 & 353 & $327^{*}$ & 3 \\
\hline 2003 & 85 & 739 & $764 * * *$ & 22 & 85 & 12.0 & 11.7 & 2 & 61 & 364 & 345 & 0 \\
\hline 2004 & 36 & 750 & $762 *$ & 22 & 36 & 11.9 & 11.7 & 6 & 12 & 313 & 298 & 0 \\
\hline 2005 & 31 & 795 & 800 & 0 & 31 & 10.5 & 10.6 & 0 & 31 & 349 & 341 & 0 \\
\hline 2006 & 5 & 748 & 751 & 0 & 5 & 12.4 & 12.2 & 0 & 3 & 307 & 313 & 0 \\
\hline 2007 & 8 & 740 & 755 & 38 & 8 & 11.8 & 11.5 & 0 & 4 & 256 & 259 & 0 \\
\hline Mean $^{\mathrm{e}}$ & 771 & 757 & $773 * * *$ & 16 & & 11.3 & $11.1 * * *$ & 6 & & 315 & $296 * *$ & 4 \\
\hline Mean $^{\mathrm{f}}$ & 25 & 779 & 789 ns & & & 11.3 & $11.2 \mathrm{~ns}$ & & & 292 & $281 \mathrm{~ns}$ & \\
\hline
\end{tabular}

${ }^{\mathrm{a}}$ Number of entries, field trials (1983-1994, 2006-2007) or experimental treatments (1995-2005), untreated and treated respectively.

${ }^{\mathrm{b}}$ Not fungicide-treated plots. ${ }^{\mathrm{c}}$ Fungicide-treated plots, single treatment during GS 454-61. ${ }^{\mathrm{d}}$ Change due to fungicide treatment for numbers of $\mathrm{N}$ exceeding payment threshold values: HLW $\geq 740 \mathrm{~g} / \mathrm{L}$, protein $\geq 10.5 \%$, Hagberg falling number $\geq 200 \mathrm{~s}$. Asterisks $(*, * *, * * *)$ indicate statistically significant differences. ${ }^{\mathrm{e}}$ Mean of all entries. ${ }^{\mathrm{f}}$ Mean of years. 
Table 2a. Net return $\left(€ \mathrm{ha}^{-1}\right)$ at three grain prices and three fungicide treatment cost levels [low $\left(33 € \mathrm{ha}^{-1}\right)$, medium $\left(67 € \mathrm{ha}^{-1}\right)$ and high $\left.\left(100 € \mathrm{ha}^{-1}\right)\right]$ estimated for 771 entries in field trials carried out 1983-2007. The net return is divided into $10 \%$ steps in decreasing order of net return.

Percent of entries in $10 \% \quad$ Net return $€$ ha $^{-1}$ at three fungicide treatment cost levels steps in descending order

of net return and at three grain prices

\begin{tabular}{|c|c|c|c|}
\hline & Low & Medium & High \\
\hline \multicolumn{4}{|l|}{ Grain price $10 € \mathrm{dt}^{-1}$} \\
\hline $0-10 \%$ & 218 to 113 & 184 to 79 & 151 to 46 \\
\hline $10-20 \%$ & 113 to 83 & 79 to 49 & 46 to 16 \\
\hline $20-30 \%$ & 83 to 63 & 49 to 29 & 16 to -4 \\
\hline $30-40 \%$ & 63 to 48 & 29 to 14 & -4 to -19 \\
\hline $40-50 \%$ & 48 to 34 & 14 to 0 & -19 to -33 \\
\hline $50-60 \%$ & 34 to 23 & 0 to -12 & -33 to -45 \\
\hline $60-70 \%$ & 23 to 8 & -12 to -26 & -45 to -59 \\
\hline $70-80 \%$ & 8 to -3 & -26 to -37 & -59 to -70 \\
\hline $80-90 \%$ & -4 to -20 & -38 to -54 & -71 to -87 \\
\hline $90-100 \%$ & $<-20$ & $<-54$ & $<-87$ \\
\hline \multicolumn{4}{|l|}{ Grain price $20 € \mathrm{dt}^{-1}$} \\
\hline $0-10 \%$ & 557 to 310 & 523 to 276 & 490 to 243 \\
\hline $10-20 \%$ & 310 to 240 & 276 to 206 & 243 to 173 \\
\hline $20-30 \%$ & 240 to 193 & 206 to 159 & 173 to 126 \\
\hline $30-40 \%$ & 193 to 158 & 159 to 124 & 126 to 91 \\
\hline $40-50 \%$ & 158 to 125 & 124 to 91 & 91 to 58 \\
\hline $50-60 \%$ & 125 to 98 & 91 to 64 & 58 to 31 \\
\hline $60-70 \%$ & 98 to 64 & 64 to 30 & 31 to -3 \\
\hline $70-80 \%$ & 64 to 37 & 30 to 3 & -3 to -29 \\
\hline $80-90 \%$ & 35 to -3 & 1 to -37 & -32 to -70 \\
\hline $90-100 \%$ & $<-3$ & $<-37$ & $<-70$ \\
\hline \multicolumn{4}{|l|}{ Grain price $30 € \mathrm{dt}^{-1}$} \\
\hline $0-10 \%$ & 896 to 507 & 862 to 473 & 829 to 440 \\
\hline $10-20 \%$ & 507 to 397 & 473 to 363 & 440 to 330 \\
\hline $20-30 \%$ & 397 to 323 & 363 to 289 & 330 to 256 \\
\hline $30-40 \%$ & 323 to 268 & 289 to 234 & 256 to 201 \\
\hline $40-50 \%$ & 268 to 216 & 234 to 182 & 201 to 149 \\
\hline $50-60 \%$ & 216 to 173 & 182 to 139 & 149 to 106 \\
\hline $60-70 \%$ & 173 to 120 & 139 to 86 & 106 to 53 \\
\hline $70-80 \%$ & 120 to 77 & 86 to 43 & 53 to 10 \\
\hline $80-90 \%$ & 74 to 14 & 40 to -20 & 7 to -53 \\
\hline $90-100 \%$ & $<14$ & $<-20$ & $<-53$ \\
\hline
\end{tabular}


Table $2 \mathrm{~b}$. Percent no. of profitable entries (net return $>0 € \mathrm{ha}^{-1}$ ) and yield increase required to obtain a profitable net return at three grain prices and three fungicide treatment cost levels, low $\left(33 € \mathrm{ha}^{-1}\right)$, medium $\left(67 € \mathrm{ha}^{-1}\right)$ and high (100€ ha $\left.{ }^{-1}\right)$ during 1983-2007.

\begin{tabular}{lcccccc}
\hline Grain price & \multicolumn{2}{c}{$\begin{array}{c}\text { Percentage of profitable entries at } \\
\text { three fungicide treatment cost levels }\end{array}$} & \multicolumn{3}{c}{ Yield increase $\left(\mathrm{dt} \mathrm{ha}^{-1}\right)$ required to } \\
& Low & Medium & High & Low & Medium & High \\
\hline $10 € \mathrm{dt}^{-1}$ & 77 & 50 & 28 & 4.5 & 9.1 & 13.6 \\
$20 € \mathrm{dt}^{-1}$ & 89 & 80 & 69 & 1.9 & 3.9 & 5.8 \\
$30 € \mathrm{dt}^{-1}$ & 91 & 86 & 82 & 1.3 & 2.5 & 3.7 \\
\hline
\end{tabular}


Figure 1. Yield $\left(\mathrm{dt} \mathrm{ha}^{-1}\right)$ in untreated and fungicide-treated (single treatment at GS 45-61) plots in farmers' fields in southern Sweden, 1983-2007. Bars represent standard deviations. Asterisks before years indicate statistically significant differences between untreated and treated plots. Data from Wiik (2009) and Wiik and Ewaldz (2009).

Figure 2. Variability (as boxplots according to SPSS, Hawkins, 2005) in net return $\left(€ \mathrm{dt}^{-1}\right)$ in scenario 12 a during $1983-2007$ with 771 entries. Medians are marked as a horizontal line in the boxes with upper and lower quartiles. T-shaped bars indicate the range, with outliers $(\bullet)$ and extreme outliers $(*)$. 


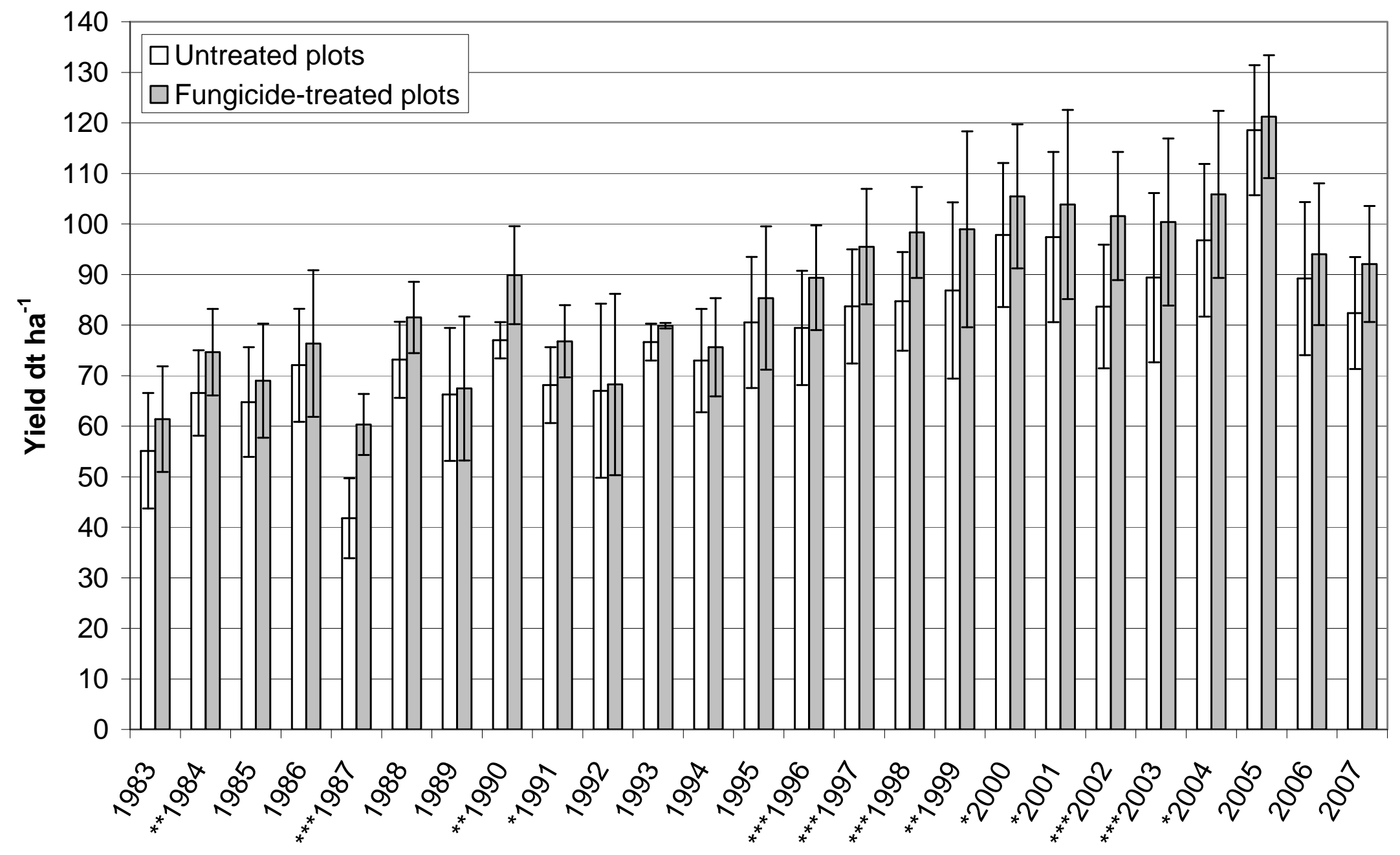

Figure 1. 


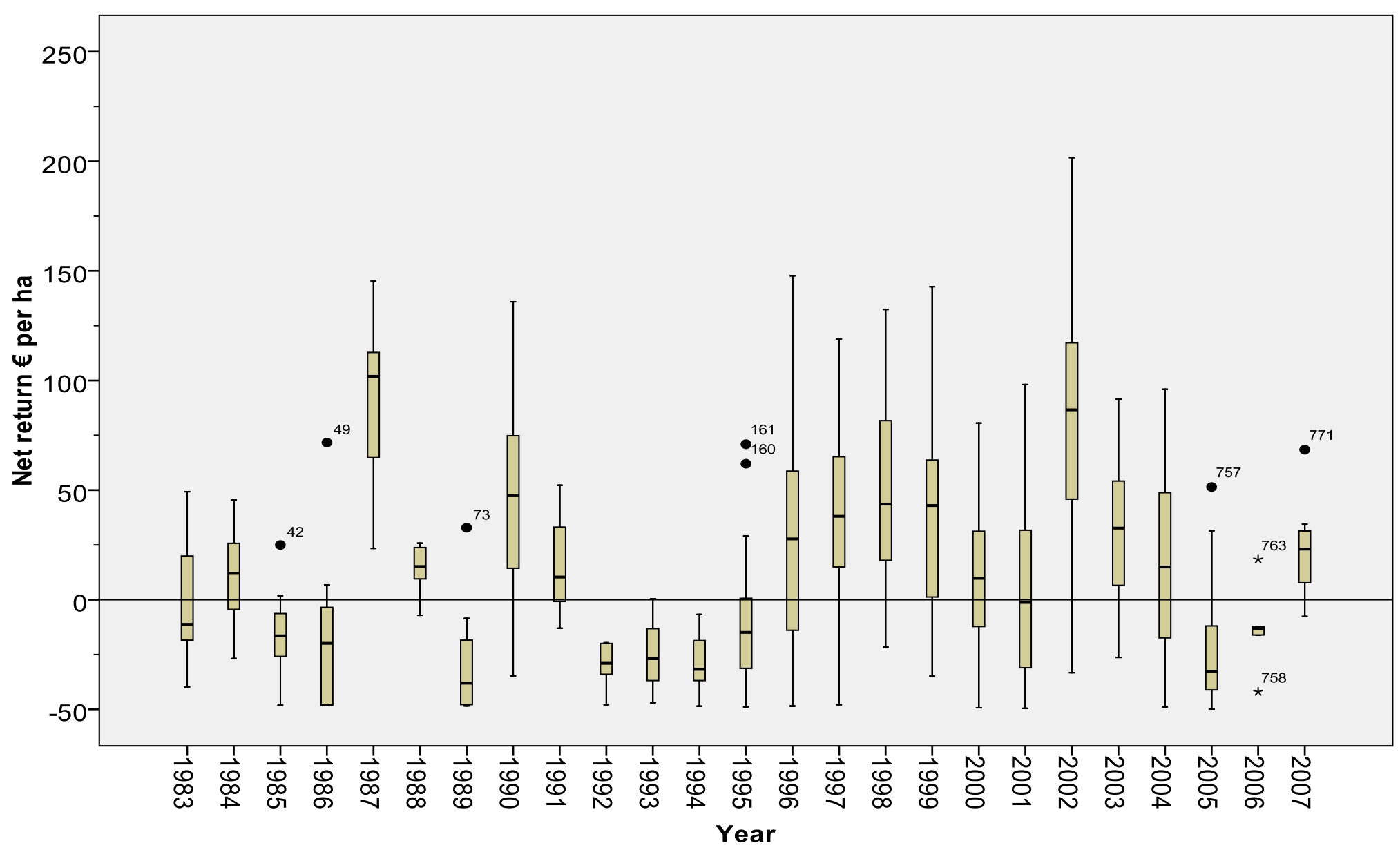

Figure 2. 